Online: https://ojs.unm.ac.id/nalar

\title{
PENGARUH PERSEPSI SISWA MENGENAI KOMPETENSI PROFESIONAL DAN PEDAGOGIK GURU TERHADAP MOTIVASI DAN HASIL BELAJAR BIOLOGI SISWA MTS SULTAN HASANUDDIN
}

\author{
Tauhidah Bachtiar ${ }^{1}$, Anita Hakim ${ }^{2}$ \\ ${ }^{1,2}$ Pendidikan Biologi, STKIPYAPTI Jeneponto \\ tauhidahbachtiar@gmail.com ${ }^{1}$
}

\begin{abstract}
Abstrak
Pendidikan adalah cara untuk membentuk sumber daya manusia yang berkualitas guna mencapai tujuan pembangunan nasional. Dengan pendidikan dapat tercipta manusia yang utuh, membentuk pribadi yang baik, beriman, bertakwa, berilmu serta membentuk manusia yang dapat menghadapi dan menyesuaikan diri dengan lingkungan. Penelitian ini pun dilakukan untuk mendapatkan informasi lebih banyak tentang bagaimana siswa berpresepsi tentang guru mereka untuk meningkatkan kualitas tenaga pendidik khususnya guru Biologi, Tujuan penelitian ini adalah untuk mengetahui persepsi siswa mengenai kompetensi profesional dan pedagogik guru, motivasi belajar Biologi siswa, hasil belajar Biologi siswa serta pengaruh antara persepsi siswa mengenai kompetensi profesional dan pedagogik guru terhadap motivasi dan hasil belajar Biologi siswa MTs. Sultan Hasanuddin. Penelitian ini termasuk jenis penelitian ex post facto yang bersifat korelasional. Instrumen yang digunakan dalam penelitian ini adalah kuesioner dan dokumentasi. Berdasarkan hasil penelitian diketahui bahwa ada pengaruh persepsi siswa mengenai kompetensi profesional dan pedagogik guru terhadap motivasi dan hasil belajar biologi siswa.
\end{abstract}

Kata Kunci: profesional, pedagogik, motivasi hasil belajar.

\section{THE INFLUENCE OF STUDENT PERCEPTION OF TEACHER'S PROFESSIONAL AND PEDAGOGIC COMPETENCY ON STUDENTS 'BIOLOGY LEARNING AND MOTIVATION MTS SULTAN HASANUDDIN}

\begin{abstract}
Education is a way to form quality human resources in order to achieve national development goals. With education, a complete human being can be created, forming a person who is good, faithful, pious, knowledgeable and forms a human who can face and adapt to the environment. This research was also conducted to obtain more information about how students perceive their teachers to improve the quality of teaching staff, especially biology teachers. The purpose of this study was to determine students' perceptions of teacher professional and pedagogical competence, student motivation to learn Biology, student learning outcomes Biology and The influence of students' perceptions of teacher professional and pedagogical competence on MTs student motivation and learning outcomes. Sultan Hasanuddin. This research is an ex post facto research that is correlational in nature. The instruments used in this study were questionnaires and documentation. Based on the results of the study, it is known that there is an effect of student perceptions of teacher professional and pedagogical competence on student motivation and learning outcomes of biology.
\end{abstract}

Keywords: professional, pedagogic, motivation for learning outcomes.

\section{PENDAHULUAN}

Pendidikan merupakan kebutuhan yang sangat penting dalam kehidupan kita. Pendidikan adalah carauntuk membentuk sumber daya manusia yang berkualitas guna mencapai tujuan pembangunan nasional. Dengan pendidikan dapat tercipta manusia yang utuh, membentuk pribadi yang baik, beriman, bertakwa, berilmu serta membentuk manusia yang dapat menghadapi dan menyesuaikan diri dengan lingkungan.pendidikan dapat diperoleh melalui pendidikan infornal dan formal. Pendidikan 
informal adalah pendidikan yang diperoleh seseorang dari pengalaman sendiri dengan sadar atau tidak sadar sepanjang hayat. Pendidikan informal ini dapat berlangsung dalam keluarga, pergaulan sehari-hari, maupun dalam masyarakat. Pendidikan formal yaitu pendidikan yang berlangsung secara bertingkat, teratur, dan mengikuti syarat tertentu, pendidikan formal ini berlangsung di sekolah [1].

Guru sebagai ujung tombak pendidikan yang langsung berada di garis depan berhadapan dengan siswa dituntut memiliki kompetensi yang memadai. Melalui guru penanaman nilai-nilai dan pembelajaran berbagai ilmu pengetahuan, pengalaman dan keterampilan yang relevan dengan masa depan dapat berlangsung. Mengingat tugas guru begitu berat maka perlunya guru untuk selalu di-update pengetahuan, wawasan, dan keterampilannya menuju kepada pengembangan profesi yang diharapkan. Sehingga tujuan utama menjadi guru profesional dapat tercapai. Menurut Ref. [2] untuk guru dapat dikatakan profesional jika memiliki indikasi dalam tiga hal yaitu (1) kompetensi yang berhubungan dengan tugas profesinya sebagai guru; (2) kompetensi yang berhubungan dengan keadaan pribadinya; (3) kompetensi yang berhubungan dengan masyarakat atau lingkungannya.

Guru yang profesional adalah guru yang memiliki kompetensi yang dapat menunjang tugastugasnya yang meliputi kompetensi pedagogik, kompetensi profesional, kompetensi sosial dan kompetensi kepribadian. Dengan memiliki kompetensi-kompetensi tersebut diharapkan guru mampu menciptakan suasana proses pembelajaran yang kondusif, aktif, kreatif, dan menyenangkan sehingga proses pembelajaran dapat dicapai secara optimal [3].

Menurut Ref. [4] guru profesional adalah pendidik yang profesional dengan tugas utama mendidik, mengajar, membimbing, melatih dan menilai peserta didik di sekolah. Tugas utama tersebut dilandasi dengan keahlian, kemahiran dan kecakapan yang berdasar pada standar mutu atau norma tertentu.

Kompetensi pedagogik pada dasarnya merupakan kemampuan guru di dalam mengelola pembelajaran. Pada proses pembelajaran, guru merupakan sebagai fasilitator bagi peserta didik dalam kegiatan perencanaan, pelaksanaan dan evaluasi pembelajaran. Interaksi yang terjadi antara guru dengan peserta didik merupakan faktor utama bagi terciptanya kegiatan pembelajaran, pendorong dan pembimbing dalam kegiatan pembelajaran. Kompetensi pedagogik guru merupakan kemampuan yang harus dimiliki oleh guru secara memadai dalam mengelola proses pembelajaran sehingga guru mampu menciptakan suasana pembelajaran yang bervariasi, aktif, inovatif, kreatif, efektif dan menyenangkan. Kompetensi tersebut dapat menyebabkan peserta didik akan tertarik dalam mengikuti proses pembelajaran yang berlangsung di kelas, sehingga siswa akan berusaha untuk mampu membelajarkan diri sendiri di luar kelas atau sekolah. Sehingga hal tersebut akan mampu meningkatkan mutu pembelajaran peserta didik itu sendiri [5].

Belajar banyak dipengaruhi oleh motivasi, baik dari dalam maupun dari luar diri seseorang. Oleh karena itu, motivasi merupakan motor penggerak yang mendorong seseorang untuk melakukan sesuatu termasuk belajar sehingga tujuan belajar tercapai, maka dalam belajar biologi juga diperlukan motivasi yang tinggi agar siswa berpeluang besar memperoleh nilai biologi yang tinggi. Tinggi rendahnya motivasi belajar siswa dapat terlihat dari keadaan siswa pada saat mengikuti pembelajaran.Perhatian siswa pada saat pembelajaran berlangsung, seriusnya siswa mengerjakan tugas yang diberikan guru serta meningkatnya hasil belajar siswa meruapakan faktor penilaian yang dapat dijadikan parameter dalam mengukur peningkatan motivasi belajar [6].

Menurut Ref. [7], bahwa ada dua pendekatan yang dapat digunakan untuk meninjau dan memahami motivasi, ialah (1) motivasi dipandang sebagai suatu proses. Pengetahuan tentang proses ini dapat membantu dosen menjelaskan tingkah laku yang diamati dan meramalkan tingkah laku yang diamati dan meramalkan tingkah laku orang lain, (2) menentukan karakteristik proses ini berdasarkan petunjuk-petunjuk tingkah laku seseorang. Petunjuk-petunjuk tersebut dapat dipercaya apabila tampak kegunaannya untuk meramalkan dan menjelaskan tingkah laku lainnya.

Hasil belajar merupakan bagian yang tidak dapat dipisahkan dalam dunia pendidikan, karena dari bagian inilah semua orang dapat melihat pencapaian individu yang telah melalui berbagai macam proses belajar. Dalam hal ini juga perbedaan pandangan 
akan hasil belajar siswa dapat dipengaruhi oleh pengalaman belajar siswa sebelumnya, di jenjang lebih rendah baik ditentukan oleh kondisi siswa dan faktor lain di luar diri siswa [8].

Hasil belajar adalah prestasi belajar yang dicapai peserta didik dalam proses kegiatan belajar mengajar dengan membawa suatu perubahan dan pembentukan tingkah laku seseorang. Untuk menyatakan bahwa suatu proses belajar dapat dikatakan berhasil, setiap tenaga pendidik memiliki pandangan masing-masing sejalan dengan filsafatnya. Namun, untuk menyamakan persepsi sebaiknya kita berpedoman pada kurikulum yang berlaku saat ini yang telah disempurnakan, antara lain bahwa suatu proses belajar mengajar tentang suatu bahan pembelajaran dinyatakan berhasil apabila tujuan pembelajaran khususnya dapat dicapai. Untuk mengetahui tercapai tidaknya tujuan pembelajaran khusus, tenaga pendidik perlu mengadakan tes formatif pada setiap menyajikan suatu bahasan kepada peserta didik. Penilaian formatif ini untuk mengetahui sejauh mana peserta didik telah menguasai tujuan pembelajaran khusus yang ingin dicapai. Suatu proses belajar mengajar dinyatakan berhasil apabila hasilnya memenuhi tujuan pembelajaran khusus dari bahan tersebut [9].

Persepsi adalah pendapat atau pandangan seseorang tentang sesuatu hal berdasarkan pengetahuan dan/ atau pemahaman yang ia miliki berdasarkan rangsangan panca indra dan pengalaman empirik yang dialami dalam proses waktu tertentu. Menurut kamus besar Bahasa Indonesia, persepsi adalah tanggapan (penerimaan) langsung dari sesuatu. Persepsi merupakan proses kognitif yang dipergunakan seseorang untuk menafsirkan dan memahami dunia sekitarnya [10].

Penelitian ini pun dilakukan untuk mendapatkan informasi lebih banyak tentang bagaimana siswa berpresepsi tentang guru mereka untuk meningkatkan kualitas tenaga pendidik khususnya guru Biologi, sehingga penulis mengangkat dan merumuskan judul "Pengaruh Persepsi Siswa Mengenai Kompetensi Profesional dan Pedagogik Guru terhadap Motivasi dan Hasil Belajar Biologi Siswa MTs. Sultan Hasanuddin.

\section{METODE PENELITIAN}

Penelitian ini menggunakan jenis penelitian ex post facto yang bersifat korelasional bertujuan menyelidiki pengaruh antara variabel bebas dan variabel tak bebas serta menguji hipotesis yang dirumuskan. Penelitian ini dilaksanakan di MTs. Sultan Hasanuddin, Waktu penelitian adalah pada tahun ajaran 2020/2021. Dalam Penelitian ini terdapat empat variabel yaitu variabel independent (bebas) yakni persepsi siswa tentang kompetensi profesional $\left(\mathrm{X}_{1}\right)$, persepsi siswa tentang kompetensi pedagogik $\left(\mathrm{X}_{2}\right)$, dan variabel dependent (tak bebas) yakni motivasi belajar $\left(\mathrm{Y}_{1}\right)$ dan hasil belajar belajar Biologi $\left(\mathrm{Y}_{2}\right)$. Instrument yang digunakan dalam penelitian ini adalah kuesioner persepsi dan motivasi siswa serta dokumentasi hasil belajar.

Populasi penelitian ini adalah seluruh siswa kelas IX MTs. Sultan Hasanuddin tahun ajaran 2020/2021, sampel penelitian dipilih secara Purposive Sampling (sampling pertimbangan), dalam penelitian ini dipilih kelas IX karena peneliti menganggap siswa kelas IX sudah lebih dewasa dan senior untuk memberikan persepsinya dalam menilai kompetensi pedagogic dan professional guru. Penelitian ini dilakukan dalam tiga tahap, yaitu tahap pertama adalah tahap persiapan, tahap kedua adalah tahap pelaksanaan penelitian dan tahap ketiga adalah evaluasi dan pelaporan hasil penelitian.

Teknik analisis data dalam penelitian ini dilakukan dengan analisis deskriptif dan statistik inferensial digunakan untuk kaitannya dengan pengujian hipotesis dalam penelitian ini, namun sebelum melakukan analisis tersebut terlebih dahulu dilakukan uji prasyarat analisis pada data hasil penelitian. Uji prasyarat yang digunakan dalam penelitian ini adalah uji normalitas, yang bertujuan untuk menguji apakah dalam model regresi variabel pengganggu atau residual memiliki distribusi normal.

\section{HASIL DAN PEMBAHASAN}

\section{Analisis Data Deskriptif}

Data yang disajikan dalam penelitian ini adalah data mengenai pengaruh persepsi siswa tentang kompetensi profesional, persepsi siswa tentang kompetensi pedagogik guru biologi dan motivasi terhadap hasil belajar siswa MTs Sultan Hasanuddin. Data nilai hasil belajar biologi diperoleh melalui dokumentasi nilai hasil ujian tengah semester ganjil tahun ajaran 2020/2021, sedangkan data variabel persepsi siswa tentang kompetensi profesional, variabel persepsi siswa tentang kompetensi pedagogik dan variabel motivasi 
belajar diperoleh dengan menggunakan angket yang dibagikan kepada siswa kelas IX MTs. Sultan Hasanuddin yang dijadikan sampel penelitian yang berjumlah. Berikut tabel data deskriptif penelitian:

Tabel 1. Analisis Deskriptif

\begin{tabular}{|c|c|c|c|c|c|}
\hline \multicolumn{6}{|c|}{ Descriptive Statistics } \\
\hline & $\mathrm{N}$ & $\begin{array}{c}\text { Minimu } \\
\mathrm{m}\end{array}$ & $\begin{array}{c}\text { Maximu } \\
\mathrm{m}\end{array}$ & Mean & $\begin{array}{c}\text { Std. } \\
\text { Deviation }\end{array}$ \\
\hline $\begin{array}{l}\text { Kompetensi } \\
\text { Profesiongl }\end{array}$ & 97 & 57 & 92 & 80.47 & 7.137 \\
\hline $\begin{array}{l}\text { Kempetensi } \\
\text { Pedagogik. }\end{array}$ & 97 & 57 & 92 & 80.47 & 7.137 \\
\hline Mativasi Belajar & 97 & 42 & 65 & 53.02 & 5.289 \\
\hline Hasil Belajar & 97 & 80 & 100 & 85.72 & 6.535 \\
\hline Valid N (listwise) & 97 & & & & \\
\hline
\end{tabular}

Berdasarkan tabel di atas, diketahui bahwa sampel dalam penelitian ini terdiri atas 97 orang/siswa. Pada penelitian ini, data mengenai persepsi siswa tentang kompetensi profesional, pedagogic dan motivasi diperoleh dengan menggunakan lembar angket yang terdiri atas 33 item pernyataan. Angket ini disebar di WA Grup kelas IX MTs. Sultan Hasanuddin Kabupaten Gowa. Dari table di atas dapat pula diketahui bahwa persepsi siswa terhadap kompetensi professional dan pedagogik guru biologi berada pada kategori baik. Begitupun motivasi belajar siswa juga berada pada kategori baik.

Untuk hasil belajar siswa, Peneliti hanya mengambil data hasil belajar biologi siswa dengan melihat nilai ujian tengah semester. Nilai yang diambil adalah nilai asli tes ujian tengah semester dan belum dilakukan remedial. Dipilihnya nilai tersebut karena nilai tersebut dianggap dapat menggambarkan hasil belajar siswa selama mengikuti semester genap.

\section{Analisis Inferensial}

Pengujian normalitas dilakukan dengan uji Kolmogorov smirnov menggunakan aplikasi komputer SPSS. Berdasarkan hasil analisis data normalitas menggunakan uji Kolmogorov smirnov diketahui bahwa data persepsi siswa mengenai kompetensi profesional dan pedagogik serta motivasi berdistribusi normal, sedangkan hasil belajar tidak berdistribusi normal. Hal tersebut dibuktikan dengan nilai yang terdapat pada tabel di bawah ini.
Tabel 2. Analisis Inferensial

Uji Korelasi

\begin{tabular}{|c|c|c|c|}
\hline \multicolumn{4}{|c|}{ Correlations } \\
\hline & & $\begin{array}{l}\text { Kompetensi } \\
\text { Erofesionsl }\end{array}$ & Moticasidelajar \\
\hline \multirow{3}{*}{ Kempetensi Profesiongl } & Pegrson Correlation & 1 & $.550^{-}$ \\
\hline & Sig. (2-tgiled) & & .000 \\
\hline & $\mathrm{N}$ & 97 & 97 \\
\hline \multirow{3}{*}{ Mativasi_Relajar } & Pesrson Correlstion & $.550^{-}$ & 1 \\
\hline & Sig. (2-toiled) & .000 & \\
\hline & $\mathrm{N}$ & 97 & 97 \\
\hline \multicolumn{4}{|c|}{ *. Correlation is significant at the 0.01 level (2-tailed). } \\
\hline \multicolumn{4}{|c|}{ Correlations } \\
\hline & & $\begin{array}{l}\text { Kompetensi } \\
\text { Erofesisnal }\end{array}$ & Hasil Belajar \\
\hline \multirow{3}{*}{ Kompetensi Profesiongl } & Pegrson Correlation & 1 & .195 \\
\hline & Sig. (2-tgiled) & & .056 \\
\hline & $\mathrm{N}$ & 97 & 97 \\
\hline \multirow{3}{*}{ Hasil Belajar } & Pearson Correlation & .195 & 1 \\
\hline & Sig. (2-tgiled) & .056 & \\
\hline & $\mathrm{N}$ & 97 & 97 \\
\hline
\end{tabular}

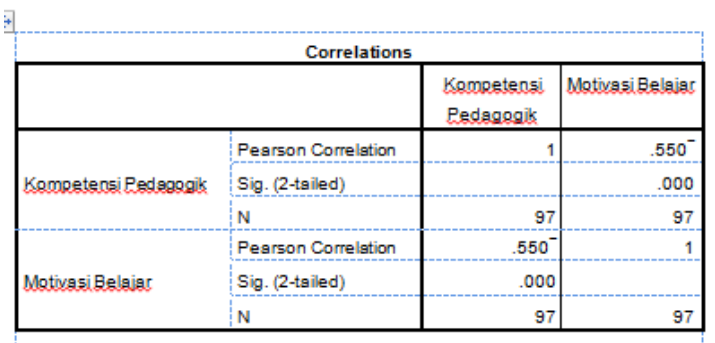

*. Correlgtion is significant at the 0.01 level (2-tailed)

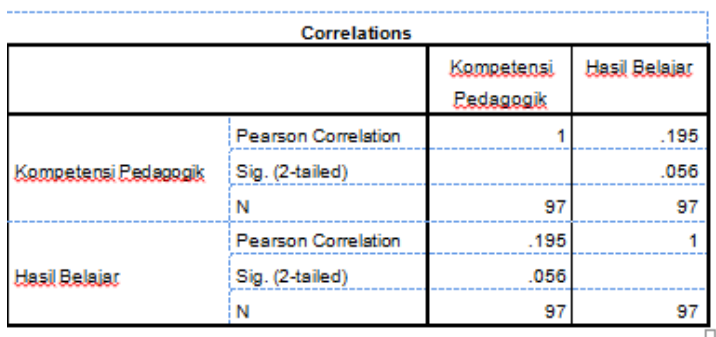

Berdasarkan hasil analisis menggunakan pengujian Person's product-moment correlation diperoleh data sig. (2-tailed) yang berarti ada pengaruh antara kompetensi profesional dan pedagogic guru dengan motivasi belajar Biologi siswa sebesart $50 \%$.

Berdasarkan hasil analisis menggunakan pengujian Person's product-moment correlation diperoleh data sig. (2-tailed) yang berarti ada pengaruh antara kompetensi profesional dan pedagogic guru dengan hasil belajar Biologi siswa sebesar $19 \%$. 


\section{Persepsi Siswa Mengenai Kompetensi Profesional dan Pedagogik Guru di MTs. Sultan Hasanuddin}

Berdasarkan analisis angket, dapat dikatakan bahwa persepsi siswa tentang kompetensi profesional guru biologi berada pada kategori baik. Adapun yang menyebabkan sehingga hasil dari pengolahan data menunjukkan bahwa persepsi siswa mengenai kompetensi profesional berada pada kategori baik karena jawaban siswa dalam kuesioner didominasi oleh pemilihan item positif dengan memilih alternatif jawaban sangat setuju dan setuju.

Hasil penelitian ini sejalan dengan penelitian yang dilakukan oleh Ref. [11] yang menyatakan bahwa berdasarkan analisis angket, dapat dikatakan bahwa persepsi siswa kelas XI IPA mengenai kompetensi profesional dan pedagogik guru biologi SMAN di Kabupaten Kepulauan Selayar berada pada kategori baik.

\section{Motivasi Belajar Siswa di MA Pesantren Kabupaten Gowa}

Berdasarkan analisis angket diperoleh bahwa motivasi belajar biologi siswa dari ketiga Madrasah Aliyah Pesantren di Kabupaten Gowa berada pada kategori Baik. Adapun yang menyebabkan sehingga hasil dari pengolahan data menunjukkan bahwa motivasi belajar Biologi siswa berada pada kategori baik karena jawaban siswa dalam kuesioner didominasi oleh pemilihan item positif dengan memilih alternatif jawaban sangat setuju dan setuju.Hal tersebut sejalan dengan hasil penelitian yang dilakukan oleh dalam Ref. [11] yang menyatakan bahwa motivasi belajar siswa SMAN dari keempat sekolah di Kabupaten Kepulauan Selayar berada pada kategori tinggi.

\section{Hasil Belajar Siswa di MTs. Sultan Hasanuddin}

Berdasarkan analisis angket diperoleh bahwa secara umum hasil belajar biologi yang diperoleh siswa cenderung berada dalam kategori sangat baik. Hal ini disebabkan oleh data deskriptif yang diperoleh dari guru bidang studi Biologi yang menjadi sampel penelitian menunjukkan bahwa nilai peserta didik didominasi dengan nilai baik yaitu berada pada rentang nilai $80-100$.

\footnotetext{
Pengaruh Persepsi Siswa mengenai Kompetensi Profesional Guru terhadap Motivasi belajar siswa di MA Pesantren Kabupaten Gowa
}

Berdasarkan hasil analisis menggunakan pengujian Person's product-moment correlation diperoleh data sig. (2-tailed) yang berarti ada pengaruh antara kompetensi profesional dan pedagogic guru dengan motivasi belajar siswa sebesart $50 \%$. Hal tersebut disebabkan oleh hasil pengolahan data yang menunjukkan bahwa persepsi siswa mengenai kompetensi profesional dan pedagogik guru Biologi berada pada kategori baik, begitupun dengan motivasi belajar Biologi siswa berada pada kategori baik sehingga terdapat pengaruh antara persepsi siswa mengenai kompetensi profesional dan pedagogic guru terhadap motivasi belajar Biologi siswa.

Kompetensi professional ini menuntut guru untuk memiliki pengetahuan yang komprehensif tentang materi-materi pelajaran yang akan diajarkan kepada peserta didik. Dengan kompetensi professional yang baik, seorang guru mampu memberikan pengetahuan yang benar kepada peserta didik sesuai mata pelajaran yang diampunya [12].

Kompetensi professional merupakan kompetensi yang harus dimiliki oleh guru yang profesional. Kompetensi tersebut harus dikembangkan dalam rangka mencapai tujuan pembelajaran di sekolah. Kompetensi profesional dipandang penting untuk dikembangkan oleh para guru karena kompetensi profesional mencakup kemampuan guru dalam penguasaan terhadap materi pelajaran dan kemampuan guru dalam pengelolaan pembelajaran. Menurut Undang-undang No. 14 Tahun 2005 tentang Guru dan Dosen, kompetensi profesional adalah kemampuan penguasaan materi pelajaran secara luas dan mendalam yang mencakup penguasaan materi kurikulum mata pelajaran di sekolah dan substansi keilmuan yang menaungi materinya, serta penguasaan terhadap struktur dan metodologi keilmuannya. Menurut PP No. 19 Tahun 2005 penjelasan pasal 28 yang dimaksud dengan kompetensi profesional adalah kemampuan penguasaan materi pembelajaran secara luas dan mendalam yang memungkinkannya membimbing peserta didik memenuhi standar kompetensi yang ditetapkan dalam standar Nasional Pendidikan [9].

Pada hakikatnya motivasi itu secara potensial bersumber dari dalam, tetapi ada yang timbul langsung dari seseorang tanpa suatu rangsangan dari luar dan ada yang timbul karena ada rangsangan atau terpancing oleh rangsangan dari luar. Sekalipun 
diakui betapa pentingnya motivasi internal, bagaimanapun juga usaha untuk menciptakan kondisi motivasional yang membangkitkan kegairahan belajar siswa adalah sangat penting dalam meningkatkan prestasi belajar siswa. Disinilah letak peranan guru untuk menciptakan kondisi motivasi itu.

Kompetensi inti guru dalam pedagogik ini meliputi : (1) menguasai karakteristik peserta didik dari aspek fisik, moral, sosial kultural emosional dan intelektual, (2) menguasai teori belajar dan prinsipprinsip pembelajaran yang mendidik, (3) mengembangkan kurikulum yang terkait dengan bidang pengembangan yang diampu, (4) menyelenggarakan kegiatan pengembangan yang mendidik, (5) memanfaatkan teknologi informasi dan komunikasi untuk kepentingan penyelenggaraan kegiatan pengembangan yang mendidik, (6) memfasilitasi pengembangan potensi peserta didik untuk mengaktualisasi berbagai potensi yang dimiliki, (7) berkomunikasi secara efektif, empatik dan santun dengan peserta didik, (8) menyelenggarakan penilaian dan evaluasi proses dan hasil belajar, (9) memanfaatkan hasil penilaian dan evaluasi untuk kepentingan pembelajaran, dan (10) melakukan tindakan reflektif untuk peningkatan kualitas pembelajaran.

\section{Pengaruh Persepsi Siswa mengenai Kompetensi Profesional dan Pedagogik Guru terhadap Hasil Belajar Siswa di MA Pesantren Kabupaten Gowa}

Berdasarkan hasil analisis menggunakan pengujian Person's product-moment correlation diperoleh data sig. (2-tailed) yang berarti ada pengaruh antara kompetensi profesional guru dengan hasil belajar biologi siswa sebesar 19\%. Hal tersebut disebabkan oleh hasil pengolahan data yang menunjukkan bahwa persepsi siswa mengenai kompetensi profesional guru Biologi berada pada kategori baik, begitupun dengan hasil belajar Biologi siswa berada pada kategori sangat baik sehingga terdapat pengaruh antara persepsi siswa mengenai kompetensi profesional guru terhadap hasil belajar Biologi siswa.

Menurut Ref. [4], guru profesional adalah pendidik yang profesional dengan tugas utama mendidik, mengajar, membimbing, melatih dan menilai peserta didik di sekolah. Tugas utama tersebut dilandasi dengan keahlian, kemahiran dan kecakapan yang berdasar pada standar mutu atau norma tertentu.

Guru yang profesional adalah guru yang memiliki kompetensi yang dapat menunjang tugastugasnya yang meliputi kompetensi pedagogik, kompetensi profesional, kompetensi sosial dan kompetensi kepribadian. Dengan memiliki kompetensi-kompetensi tersebut diharapkan guru mampu menciptakan suasana proses pembelajaran yang kondusif, aktif, kreatif, dan menyenangkan sehingga proses pembelajaran dapat dicapai secara optimal [3].

Hasil belajar adalah prestasi belajar yang dicapai peserta didik dalam proses kegiatan belajar mengajar dengan membawa suatu perubahan dan pembentukan tingkah laku seseorang. Untuk menyatakan bahwa suatu proses belajar dapat dikatakan berhasil, setiap tenaga pendidik memiliki pandangan masing-masing sejalan dengan filsafatnya. Namun, untuk menyamakan persepsi sebaiknya kita berpedoman pada kurikulum yang berlaku saat ini yang telah disempurnakan, antara lain bahwa suatu proses belajar mengajar tentang suatu bahan pembelajaran dinyatakan berhasil apabila tujuan pembelajaran khususnya dapat dicapai. Untuk mengetahui tercapai tidaknya tujuan pembelajaran khusus, tenaga pendidik perlu mengadakan tes formatif pada setiap menyajikan suatu bahasan kepada peserta didik. Penilaian formatif ini untuk mengetahui sejauh mana peserta didik telah menguasai tujuan pembelajaran khusus yang ingin dicapai. Suatu proses belajar mengajar dinyatakan berhasil apabila hasilnya memenuhi tujuan pembelajaran khusus dari bahan tersebut [9].

\section{KESIMPULAN}

Berdasarkan hasil penelitian diketahui bahwa ada pengaruh persepsi siswa mengenai kompetensi profesional dan pedagogik guru terhadap motivasi dan hasil belajar biologi siswa. Adapun persepsi siswa kelas IX tentang kompetensi profesional guru biologi MTs. Sultan Hasanuddin berada pada kategori baik.

\section{DAFTAR PUSTAKA}

[1] D. Firdiani. "Pengaruh Persepsi Siswa Terhadap Pola Asuh Orang Tua dan Tingkat Pendidikan Orang Tua Terhadap Motivasi dan Hasil Belajar Biologi Siswa Kelas X dan XI IPA SMAN 8 Makassar”. Tesis. Program 
Studi Pendidikan Biologi. Universitas Negeri Makassar, 2016.

[2] H. Uno. "Profesi Kependidikan". Jakarta: Bumi Aksara Aksara. 2012.

[3] Sulistiyani. "Hubungan Kompetensi Pedagogik dan Motivasi Mengajar dengan Produktivitas Guru IPA SMP Negeri SeKabupaten Lampung Timur”. Bioedukasi Jurnal Pendidikan Biologi Universitas Muhammadiyah Metro. 6 (2), 134-142, 2015.

[4] Abimanyu dan Amir. "Modul Pendidikan dan Latihan Profesi Guru". Makassar: Universitas Negeri Makassar, 2011.

[5] M. Siregar., F. Harahap, H. Sipahutar. "Analisis Kompetensi Pedagogik Guru Biologi SMA SeKota Binjai”. Jurnal Pendidikan Biologi. No 2, Edisi April. 2016.

[6] R. Riyanti. "Hubungan Persepsi Siswa Tentang Kepemimpinan Guru dan Motivasi Belajar terhadap Hasil Belajar Biologi Siswa SMP Kelas VIII Di Kabupaten Maros". Tesis. Program Studi Pendidikan Biologi. Universitas Negeri Makassar, 2015.

[7] Hamalik. "Kurikulum dan Pembelajaran". Jakarta: Bumi Aksara, 2014.

[8] S. Wasti. "Hubungan Minat Belajar dengan Hasil Belajar Mata Pelajaran Tata Busana di Madrasah Aliyah Negeri 2 Padang". EJournal Home Economic and Tourism, 2013.

[9] Andriani. "Hubungan Persepsi Mahasiswa Pada Kompetensi Professional Dosen Biologi dan Motivasi Belajar terhadap Hasil Belajar Mahasiswa Program Studi Pendidikan Biologi FKIP Unismuh Makassar”. Tesis. Program Studi Pendidikan Biologi. Universitas Negeri Makassar, 2017.

[10] Hodsay. "Persepsi Mahasiswa terhadap Kompetensi Dosen Program Studi Pendidikan Akuntansi FKIP Universitas PGRI Palembang". Jurnal Riptesi Pendidikan PGRI, Volume 9. No. 1, 2013.
[11] L. Hidayat. "Pengaruh Persepsi Siswa Tentang Kompetensi Profesional dan Kompetensi Pedagogik Guru Biologi Terhadap Motivasi dan Hasil Belajar Siswa SMAN Di Kabupaten Kepulauan Selayar". Tesis. Program Studi Pendidikan Biologi. Universitas Negeri Makassar, 2017.

[12] Setiadi. "Publikasi Ilmiah Guru (Kegiatan Profesional Guru sebagai Pengembangan Keprofesionalan Berkelanjutan)". Yogyakarta: Deepublish. 2015. 